\title{
Efek steaming up menggunakan Gliricidia sepium pada kambing perah selama masa periode kering terhadap pertumbuhan anak Kambing Peran- akan Etawah
}

\section{Effect of steaming up by Gliricidia sepium to dairy goats during dry period on goat kid growth of Etawah Crossbred}

\author{
R. Dharmawan *, P. Surjowardojo, dan T. E. Susilorini \\ Fakultas Peternakan Universitas Brawijaya, Malang \\ Jalan Veteran, Malang (65145) Indonesia
}

Submitted: 5 Maret 2019, Accepted: 16 Juli 2019

\begin{abstract}
ABSTRAK: Penelitian ini dilakukan untuk mengetahui efek steaming up menggunakan Gliricidia sepium selama periode kering terhadap penampilan produksi anak kambing PE. Dua belas ekor induk kambing dipilih berdasarkan periode laktasi dengan perlakuan sebagai berikut: (1) P0 sebagai kontrol, (2) P1 sebagai perlakuan steaming up $0,4 \% \mathrm{BK}$, dan (3) P2 sebagai perlakuan steaming up $0,8 \% \mathrm{BK}$. Seluruh perlakuan diberikan pakan basal konsentrat $0,9 \%$ BK dan Pennisetum purpureum secara $a d-$ libitum. Data yang diperoleh dianalisis menggunakan Anova dengan Rancangan Acak Kelompok. Perbedaan data dianalisis dengan Uji Jarak Berganda Duncan. Perlakuan P2 menghasilkan tingkat penurunan bobot badan dan BCS yang rendah pada saat partus dibandingkan P0 dan P1, namun tidak menunjukkan perbedaan yang nyata $(\mathrm{P}>0,05)$. Bobot lahir, bobot sapih, dan PBBH anak kambing tidak berbeda nyata antar perlakuan $(\mathrm{P}>0,05)$. Kesimpulan dari penelitian ini adalah bahwa steaming up menggunakan Gliricidia sepium sebesar 0,8\% berdasarkan kebutuhan BK pada periode kering menunjukkan laju penurunan bobot badan dan BCS yang rendah. Perlakuan steaming up juga menunjukkan rataan bobot lahir, bobot sapih, dan PBBH tertinggi.
\end{abstract}

Kata kunci: berat lahir; berat sapih; pertambahan bobot badan harian; Peranakan Etawah.

ABSTRACT: The study was conducted to evaluate the effect of steaming up using Gliricidia sepium in dry period on the performanceof Etawah Crossbred goats kid production. Twelve goats were selected based on lactation period with the following treatments: (1) T0 as a control, (2) T1 as a treatment for steaming up $0.4 \% \mathrm{DM}$, and (3) T2 as a steaming up $0.8 \% \mathrm{DM}$. All experiment restricted to the same basal concentrate diet $0.9 \%$ DM and ad-libitum of Pennisetum purpureum. The obtained data were analyzed using analysis of variance. The difference in data was analyzed by Duncan's Multiple Distance Test. The result was T2 treatment had a low level of weight loss and BCS at parturition compared to $\mathrm{T} 0$ and $\mathrm{T} 1$, but had no significant different $(\mathrm{P}>0.05)$. Birth weight, weaning weight, and ADG of goats kid were not significantly different between the treatments $(\mathrm{P}>0.05)$. The conclusion of this study is that steaming up using Gliricidia sepium by $0.8 \%$ based on DM needs in the dry period showed a low decrease in the rate of body weight and low BCS. The steaming up treatment also shows the highest birth weight, weaning weight, and highest ADG.

Keywords: average daily gain; birth weight; weaning weight; Etawah Crossbred.

*Corresponding Author: career.rachmadrmwn@gmail.com

DOI: 10.21776/ub.jiip.2019.029.02.02 


\section{PENDAHULUAN}

Mortalitas anak kambing Peranakan Etawah (PE) yang tinggi diakibatkan oleh rendahnya bobot lahir $10,7 \%$ (Suranindyah, dkk. 2009) dan berdampak pada bobot sapih yang rendah (Soberon, et al. 2012). Pertambahan bobot badan harian $(\mathrm{PBBH})$ di awal kehidupan berkaitan dengan kesehatan ternak dan potensi produksi selanjutnya pada kambing perah (Deeming, et al. 2016). Penelitian Soberon, et al. (2012) menunjukkan hubungan positif antara PBBH dalam kehidupan awal anak kambing dengan produksi susu. Rataan PBBH yang rendah akan menyebabkan anak kambing mati atau mengurangi potensi produksi, sehingga peternak skala kecil mengalami kerugian. Tingkat pertumbuhan awal anak kambing dipengaruhi oleh faktor manajemen pemberian pakan induk selama periode kering. Kualitas pakan yang tidak berkelanjutan dan rendah nutrisi menyebabkan induk kambing mengalami kekurangan nutrien untuk menunjukkan potensi genetiknya. Peningkatan produktivitas dapat dilakukan dengan memperbaiki manajemen pemberian pakan. Induk kambing PE membutuhkan nutrisi yang sesuai status fisiologisnya pada periode kering, terutama konsumsi energi dan protein.

Steaming up pada kambing perah dilakukan selama periode kering sebelum partus yang berfungsi untuk memberi nutrisi pada induk dan calon anak (Sirohi, et al. 2014). Kebutuhan nutrisi yang memadai pada periode kering berdampak pada penampilan produksi kambing perah dan kesejahteraan ternak (NRC, 2001). Chellapandian (2016) steaming up selama kebuntingan akhir akan memastikan pasokan nutrisi yang cukup dan menghasilkan pertumbuhan yang baik dari induk dan calon anak. Konsumsi pakan tinggi energi akan meningkatkan $\mathrm{PBBH}$ pada induk bunting dan calon anak (Sahu, et al. 2013). Selama kebuntingan juga terjadi peningkatan kebutuhan protein karena adanya peningkatan proses katabolik asam amino (Bell, 1995). Penampilan produksi yang baik untuk induk dan calon anak yang sedang tumbuh dapat dilakukan dengan steaming up Gliricidia sepium.

Kecernaan bahan kering Gliricidia sepium adalah 37,99\% -54,61\% (Daning dan Foekh, 2018) sampai 48-77\% (Cakra, dan Trisnadewi, 2016). Kandungan protein pada Gliricidia sepium sekitar 30,01\%26,38\% (Anis, et al. 2016). Herwati dan Royani (2017) juga menjelaskan bahwa Gliricidia sepium memiliki kandungan kumarin yang merupakan anti nutrisi yang menyebabkan bau dan rasa pahit yang kuat sehingga dapat menurunkan palatabilitas. Perlua adanya perlakuan pakan sehingga mampu menurunkan senyawa kumarin sebelum diberikan pada ternak. Tingginya kecernaan bahan kering dan bahan organik pada Gliricidia sepium diharapkan mampu memperbaiki produksi ternak. Tujuan dari penelitian ini adalah untuk mengetahui variasi pertumbuhan anak kambing di peternakan kambing PE di Singosari, memberikan tolok ukur bagi peternak kambing PE.

\section{MATERI DAN METODE \\ Lokasi penelitian}

Penelitian ini dilakukan pada peternakan kambing PE di Singosari, Kabupaten Malang. Penelitian ini dimulai pada tanggal 14 Oktober sampai 14 Desember 2018.

\section{Materi}

12 ekor kambing PE singleparous dan multiparous pada periode kering terbagi menjadi tiga kelompok. Setiap kelompok terdiri atas kambing PE periode laktasi kedua dan ketiga. Pakan basal konsentrat yang diberikan yaitu $0,9 \%$ BK dari bobot badan dan pemberian Pennisetum purpureum secara ad-libitum. Kambing pada periode kering dibagi menjadi tiga kelompok sesuai perlakuan sebagai 
berikut:

P0 : pakan basal dan Gliricidia sepium

Hasil analisis kandungan nutrien bahan 0,0\% BK dari Bobot Badan.

P1 : pakan basal dan Gliricidia sepium pakan dan suplemen ditampilkan pada 0,4\% BK dari Bobot Badan.

P2 : pakan basal dan Gliricidia sepium 0,8\% BK dari Bobot Badan. Tabel 1 .

Tabel 1. Kandungan nutrisi bahan pakan basal dan pakan perlakuan

\begin{tabular}{lccccc}
\multirow{2}{*}{ Bahan pakan } & \multicolumn{5}{c}{ Kandungan nutrisi (\%) } \\
\cline { 2 - 6 } & Bahan kering & Kadar abu & Protein kasar & Lemak kasar & Serat kasar \\
\hline Konsentrat $^{\mathrm{A}}$ & 89,18 & 05,17 & 16,35 & 06,09 & 06,03 \\
\hline Pennisetum purpureum $^{\mathrm{A}}$ & 79,55 & 15,18 & 14,66 & 01,83 & 24,21 \\
\hline Gliricidia sepium $^{\mathrm{B}}$ & 93,41 & 08,72 & 20,01 & 03,05 & 16,09
\end{tabular}

Keterangan: $\quad{ }^{A}$ Laboratorium Pakan Dinas Peternakan Jawa Timur (2018)

${ }^{B}$ Laboratorium HMT Universitas Brawijaya, Malang (2018)

\section{Koleksi data dan analisis}

Konsumsi pakan dan pakan sisa ditimbang selama seminggu sebelum prediksi induk partus menggunakan timbangan digital. Pakan pemberian dan pakan sisa selanjutnya dianalisis menggunakan analisa proksimat.

\section{Data anak kambing}

Pengelompokan anak kambing dilakukan berdasarkan litter size pada setiap perlakuan. Penimbangan bobot lahir dilakukan 0-jam pasca partus. Penimbangan $\mathrm{PBBH}$ anak kambing dilakukan setiap hari menggunakan timbangan digital pada pukul 06:00 WIB sebelum diberikan konsumsi susu. Jumlah pemberian susu pada anak kambing dilakukan setiap hari, sesuai kebutuhan ternak berdasarkan bobot badan (BB) sebagai berikut: (1) Pemberian susu sebanyak $8 \%$ pada minggu kedua; (2) $9 \%$ pada minggu ketiga; (3) 10\% pada minggu keempat; (4) $8 \%$ pada minggu kelima. Pemberian susu dilakukan 4 kali setiap hari selama 5 minggu pasca partus.

\section{HASIL DAN PEMBAHASAN Konsumsi nutrient pakan}

Pengaruh perlakuan steaming up terhadap konsumsi bahan kering (BK), bahan organik (BO), dan protein kasar (PK) ditampilkan pada Tabel 2.

Tabel 2. Konsumsi nutrien pakan

\begin{tabular}{ccccc}
\hline \multirow{2}{*}{ Parameter } & \multirow{2}{*}{ satuan } & \multicolumn{3}{c}{ Perlakuan } \\
\cline { 3 - 5 } & & P0 & P1 & P2 \\
\hline Rataan kebutuhan BK & g/ekor/day & 1963,12 & 1952,24 & 1903,30 \\
Rataan konsumsi BK & g/ekor/day & $1629,44^{\mathrm{a}}$ & $1706,00^{\mathrm{b}}$ & $1760,36^{\mathrm{c}}$ \\
Konsumsi BK/BB induk & $\%$ & 3,02 & 3,29 & 3,53 \\
Rataan konsumsi BO & g/ekor/day & $1426,02^{\mathrm{a}}$ & $1504,12^{\mathrm{b}}$ & $1562,28^{\mathrm{c}}$ \\
Rataan kebutuhan PK & g/ekor/day & 168,56 & 167,40 & 163,53 \\
Rataan konsumsi PK & g/ekor/day & $123,13^{\mathrm{a}}$ & $131,34^{\mathrm{b}}$ & $138,09^{\mathrm{c}}$ \\
\hline
\end{tabular}

Keterangan: ${ }^{\mathrm{a}-\mathrm{b}}$ Superskrip yang berbeda pada baris yang sama menunjukkan perbedaan yang nyata $(\mathrm{P}<0,05)$. 
Konsumsi BK ransum pada ternak ruminansia memiliki peranan penting untuk menyediakan nutrien yang dibutuhkan ternak untuk hidup pokok, produksi, dan reproduksi. Konsumsi BK yang rendah akan mengakibatkan ternak menggunakan nutrien untuk memenuhi kebutuhan pokoknya sehingga produksi dan reproduksi menjadi rendah. Konsumsi BK dalam penelitian ini adalah 1426,021562,28 g/ekor/hari, lebih tinggi dari Suwignyo, dkk. (2016) kebutuhan konsumsi BK untuk hidup pokok kambing dengan berat badan $40-50 \mathrm{~kg}$ yaitu antara 10801280 g/ekor/hari. Tingkat konsumsi BK dipengaruhi oleh berbagai faktor, yaitu bobot badan, umur, stres lingkungan yang disebabkan oleh sifat fisik, komposisi pakan, dan kapasitas rumen. Rataan konsumsi BK pada P0 belum memenuhi standar kebutuhan kambing PE bunting tua sebesar 3,32\% BK berdasarkan bobot badan (NRC, 1981) sedangkan perlakuan P1 dan P2 telah memenuhi standar kebutuhan BK. Konsumsi BK yang rendah saat penelitian disebabkan karena kambing yang selektif memilih pakan. Kambing cenderung memilih pakan Gliricidia sepium dibandingkan dengan rumput gajah. Kelompok dengan perlakuan steaming up memiliki nilai konsumsi BK yang tinggi karena konsumsi Gliricidia sepium sesuai dengan kapasitas rumen kambing bunting dibandingkan dengan konsumsi Pennisetum purpureum, sehingga pakan bisa dikonsumsi lebih banyak.

Konsumsi BO pada P2 adalah 1562,28 g/ekor/hari lebih tinggi dibandingan konsumsi BO pada P1 adalah 1504,12 g/ekor/hari dan konsumsi BO pada P0 adalah 1426,02 g/ekor/hari. Konsumsi BO penelitian lebih tinggi dibandingkan Novita, dkk. (2005) dengan konsumsi BO sebanyak 912-1051 g/ekor/hari. Konsumsi PK pada P2 adalah 138,09 g/ekor/hari lebih tinggi dibandingkan dengan konsumsi PK pada $\mathrm{P} 0$ adalah 123,13 g/ekor/hari dan P1 adalah 131,34 g/ekor/hari. Konsumsi PK penelitian lebih tinggi dari Nuraini, Budisatria, dan Agus (2014) bahwa konsumsi PK kambing PE bunting tua adalah 80 g/ekor/hari. Menurut NRC (1981) PK yang dibutuhkan untuk bobot badan kambing $(50 \mathrm{~kg})$ berkisar antara 157 g/ekor/hari.

\section{Penampilan produksi induk kambing}

Pengaruh perlakuan steaming up terhadap penampilan produksi induk kambing ditampilkan pada Tabel 3.

Tabel 3. Penampilan produksi induk kambing

\begin{tabular}{lllll}
\hline \multicolumn{1}{c}{ Parameter } & \multirow{2}{*}{ Satuan } & \multicolumn{3}{c}{ Perlakuan } \\
\cline { 3 - 5 } & & \multicolumn{1}{c}{$\mathrm{P} 0$} & $\mathrm{P} 1$ & $\mathrm{P} 2$ \\
\hline Rataan BB pra partus & $\mathrm{kg}$ & $54,38 \pm 1,11$ & $54,00 \pm 2,83$ & $52,75 \pm 2,99$ \\
Rataan BB pasca partus & $\mathrm{kg}$ & $42,25 \pm 1,71$ & $44,00 \pm 3,94$ & $44,25 \pm 0,65$ \\
\% Kehilangan BB pra dan pasca partus & $\%$ & 22,30 & 18,52 & 16,11 \\
Rataan BCS pra partus & - & $3,38 \pm 0,48$ & $3,63 \pm 0,25$ & $3,50 \pm 0,41$ \\
Rataan BCS pasca partus & - & $2,88 \pm 0,25$ & $3,25 \pm 0,29$ & $3,25 \pm 0,29$ \\
\% Kehilangan BCS pra dan pasca partus & $\%$ & 14,79 & 10,47 & 7,14 \\
Litter size & ekor & 1,75 & 1,50 & 1,50 \\
\hline
\end{tabular}

Steaming up menggunakan Gliricidia sepium tidak menunjukkan laju penurunan kehilangan bobot badan yang signifikan $(\mathrm{P}>0,05)$. Namun pada Tabel 3 . Menunjukkan bahwa perlakuan P2 terjadi penurunan nilai bobot badan sebesar
16,11\%; perlakuan P1 terjadi penurunan nilai bobot badan sebesar 18,52\%; sedangkan perlakuan $\mathrm{P} 0$ terjadi penurunan bobot badan sebesar 22,30\%. Sultana, et al. (2012) steaming up pada periode kering dapat meningkatkan $\mathrm{PBBH}$ dan kehilangan 
bobot badan saat partus (Sahu, et al. 2013). Sirohi, et al. (2014) perlakuan suplementasi konsentrat selama periode kering dapat mengurangi resiko kehilangan bobot badan yang drastis pada awal laktasi. Praveena, et al. (2014) rataan kehilangan bobot badan induk kambing terendah terjadi pada perlakuan penambahan konsentrat pada periode kering.

Tabel 3. Menunjukkan bahwa perlakuan P0 terjadi penurunan nilai BCS sebesar 14,79\%; perlakuan $\mathrm{P} 1$ terjadi penurunan nilai BCS sebesar 10,47\%; sedangkan perlakuan $\mathrm{P} 2$ terjadi penurunan BCS sebesar 7,14\%. Rendahnya kehilangan nilai BCS diakibatkan pada saat kambing bunting tua mendapatkan pakan dengan kualitas baik yang mecukupi kebutuhan fisiologisnya. Kecukupan kebutuhan fisologis pada kambing perah mengakibatkan ternak tidak merombak sebagian besar jaringan tubuhnya untuk produksi susu, sehingga skor BCS tidak turun secara drastis. Sirohi, et al. (2014) steaming up dapat meningkatkan status energi pada kambing ketika partus, menurunkan laju kehilangan BCS serta menghasilkan bobot lahir anak kambing yang lebih tinggi. Sedangkan rataan litter size pada induk kambing $\mathrm{PE}$ pada penelitian adalah P0 (1,75 ekor); P1 (1,50 ekor); dan P2 (1,50 ekor). Nilai litter size tersebut lebih rendah apabila dibandingkan dengan penelitian Kaunang, Suyadi, dan Wahjuningsih (2012) bahwa

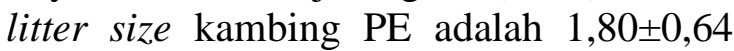
ekor. Rataan litter size kambing PE penelitian masih dikatakan baik.

\section{Penampilan pertumbuhan anak kambing}

Penampilan pertumbuhan anak kambing PE selama 4 minggu ditampilkan pada Tabel 4.

Tabel 4. Penampilan produksi anak kambing kambing PE selama 4 minggu

\begin{tabular}{lccc}
\hline \multirow{2}{*}{ Parameter } & \multirow{2}{*}{ Perlakuan } & \multicolumn{2}{c}{ Litter size } \\
\cline { 3 - 4 } & & $3755 \pm 000^{\mathrm{a}}$ & 2 \\
\hline \multirow{2}{*}{ Bobot lahir (g) } & P0 & $4000 \pm 028^{\mathrm{m}}$ & $3300 \pm 099,7^{\mathrm{b}}$ \\
& P1 & $4140 \pm 123^{\mathrm{x}}$ & $3462 \pm 064,3^{\mathrm{n}}$ \\
\multirow{3}{*}{ Bobot sapih (g) } & P2 & $6732 \pm 000$ & $6406 \pm 098,2^{\mathrm{y}}$ \\
& P0 & $7021 \pm 103$ & $6474 \pm 146,2$ \\
PBBH (g) & P1 & $7292 \pm 115^{\mathrm{a}}$ & $6643 \pm 049,4^{\mathrm{b}}$ \\
& P2 & $106 \pm 0,000$ & $111 \pm 4,135$ \\
& P0 & $108 \pm 2,677$ & $112 \pm 4,459$ \\
\hline
\end{tabular}

Keterangan: ${ }^{a-b ; m-n ; x-y}$ superskrip yang berbeda pada baris yang sama menunjukkan perbedaan yang nyata antar kelompok $(\mathrm{P}<0,05)$. Perlakuan steaming up tidak memberikan perbedaan yang nyata terhadap bobot lahir, bobot sapih, dan PPBH antar perlakuan $(\mathrm{P}>0,05)$.

\section{Bobot lahir}

Tabel 4. Menunjukkan bahwa rataan bobot lahir kelahiran tunggal pada perlakuan P0, P1, dan P2 berturut-turut adalah 3755 g; 4000 g; dan 4140 g. Sedangkan bobot lahir kelahiran kembar pada perlakuan P0, P1, dan P2 berturut-turut adalah 3300 g; 3348 g; dan 3462 g. Hasil analisa statistik menunjukkan perlakuan steaming up menggunakan Gliricidia sepium tidak menunjukkan perbedaan nyata terhadap bobot lahir. Namun perlakuan steaming up memberikan hasil tertinggi dibandingkan perlakuan kontrol. Bobot lahir kelahiran kembar lebih rendah dibandingkan kelahiran tunggal dikarenakan adanya kompetisi mendaptakan nutrisi dari induk pada periode kering. Steaming up pada kebuntingan kembar mampu memberikan nutrisi yang baik sehingga didapatkan bo- 
bot lahir kembar optimal. Sirohi, et al. (2014) steaming up dapat meningkatkan status energi pada induk kambing bunting tua ketika partus serta menghasilkan bobot lahir anak kambing yang lebih tinggi. Sahu, et al. (2013) mengemukakan bahwa kehilangan BCS yang lebih besar pada saat periode kering maupun awal laktasi juga akan mempengaruhi bobot lahir anak kambing.

\section{Bobot sapih}

Tabel 4. Menunjukkan bahwa rataan bobot sapih kelahiran tunggal pada perlakuan P0, P1, dan P2 berturut-turut adalah 6732 g; 7021 g; dan 7292 g. Sedangkan bobot sapih kelahiran kembar pada perlakuan P0, P1, dan P2 berturut-turut adalah 6406 g; 6474 g; dan 6643 g. Hasil analisa statistik menunjukkan perlakuan steaming up menggunakan Gliricidia sepium tidak menunjukkan perbedaan nyata terhadap bobot sapih. Namun perlakuan steaming up memberikan hasil tertinggi dibandingkan perlakuan kontrol. Bobot sapih sangat dipengaruhi oleh bobot lahir, jenis kelamin, stress, dan manajemen pemeliharaan. Nnadi, Kamalu, and Onah (2007) mengemukakan bahwa induk kambing dengan perlakuan steaming up tinggi nutrisi pada periode kering akan menghasilkan bobot lahir yang lebih tinggi saat lahir. Bhaskar, et al. (2015) bobot lahir yang tinggi memiliki korelasi yang positif pada bobot sapih pada umur 3 bulan.

\section{Pertambahan bobot badan harian}

Tabel 4. Menunjukkan bahwa rataan PBBH kelahiran tunggal pada perlakuan $\mathrm{P} 0, \mathrm{P} 1$, dan $\mathrm{P} 2$ berturut-turut adalah $106 \mathrm{~g}$; 108 g; dan 113 g. Sedangkan PBBH kelahiran kembar pada perlakuan P0, P1, dan P2 berturut-turut adalah $111 \mathrm{~g} ; 112 \mathrm{~g}$; dan $114 \mathrm{~g}$. Hasil analisa statistik menunjukkan perlakuan steaming up menggunakan Gliricidia sepium tidak menunjukkan perbedaan nyata terhadap PBBH. Namun perlakuan steaming up memberikan hasil tertinggi dibandingkan perlakuan kontrol. Tidak adanya perbedaan tersebut dimungkinkan karena anak kambing mendapat nutrisi yang cukup dengan sistem pemeliharaan intensif. Pemeliharaan intensif dilakukan melalui pemberian susu sesuai dengan bobot badan anak kambing. Hasil tersebut sesuai dengan penelitian Novita, dkk. (2005) bahwa pertambahan bobot badan harian anak kambing kambing $\mathrm{PE}$ dengan perlakuan pakan jerami terfermentasi adalah 96-114 g/ekor/hari. Ditambahkan Budisatria, Ibrahim , and Maharani (2018) bahwa PBBH anak kambing kambing PE dengan rambut hitam-putih, coklat-putih, dan campuran ketiganya berturut-turut adalah $118 \mathrm{~g} / \mathrm{hari}, 128 \mathrm{~g} / \mathrm{hari}$, dan $121 \mathrm{~g} /$ hari. Chaturvedi, Mann, and Karim (2014) terdapat perbedaan signifikan dalam pertambahan bobot badan harian karena perlakuan steaming up selama 2 bulan pada periode kering.

\section{KESIMPULAN}

Steaming up menggunakan Gliricidia sepium sebesar $0,8 \%$ berdasarkan kebutuhan BK pada periode kering menunjukkan laju penurunan bobot badan dan BCS yang rendah. Perlakuan steaming up juga menunjukkan rataan bobot lahir, bobot sapih, dan PBBH lebih baik dibandingkan perlakuan kontrol.

\section{UCAPAN TERIMAKASIH}

Kami mengucapkan terimaksih kepada kepala dan staff UPT PT dan HMT Singosari yang telah membantu selama penelitian.

\section{DAFTAR PUSTAKA}

Anis, S.D., D.A. Kaligis, B. Tulung, and Aryanto. 2016. Leaf quality and yield of Gliricidia sepium (Jacq) steud under different population density and cutting interval in coconut plantation. Journal of the Indonesian Tropical Animal Agriculture, 41(2), 91-98. doi: 10.14710/jitaa.41.2.91-98. 
Bell, A. W. 1995. Regulation of organic nutrient metabolism during transition from late pregnancy to early lactation. J. Anim. Sci., 73(2), 2804-2819.

Bhaskar, S.K., Yadav, S.B.S, Nagda, R.K., Pannu, U., Singh, H. and Nirbhan, L.K. 2015. Growth performance of Sirohi goats in their home tract. Indian $J$. Small Rum., 21(2), 230-233. doi:10.5958/09739718.2015.00049.5

Budisatria, I.G.S., A. Ibrahim, and D. Maharani. (2018). Pre-weaning of Etawah grade kids based on doe's hair color differences. Paper presented at The $7^{\text {th }}$ International Seminar on Tropical Animal Production Contribution of Livestock Production on Food Sovereignty in Tropical Countries, (pp. 818-823). Yogyakarta, Indonesia.

Cakra, I.G.L.O dan A.A.A.S. Trisnadewi. 2016. Penggantian daun gamal (Gliricidia sepium) dengan kaliandra (Calliandra calothyrsus) dalam ransum kambing terhadap kadar urea darah dan deposisi nutrien. Majalah Ilmiah Peternakan, 19(3), 110-114.

Chaturvedi, O. H., Mann, J. S. and Karim, S. A. 2010. Effect of concentrate supplementation to ewes grazing on community rangelands during late gestation and early lactation. Indian J. Small Rum., 16(1), 97-100.

Chellapandian, M. 2016. Effect of concentrate supplementation on the growth performance and economics of Kilakarsal Sheep. Global J. Res. Analysis, 5(6), 37-38.

Daning, D. R. A., and B. Foekh. 2018. Evalluation of production and nutrient qualityon parts of leaves and bark wood Calliandra callotirsus and Gliricidia sepium. Animal Science, 16(1), 711.
Deeming, L.E., N.J. Beausoleil, K.J. Stafford, J.R. Webster, and G. Zobel1. 2016. Brief Communication: Variability in growth rates of goat kids on 16 New Zealand dairy goat farms. Proceedings of the New Zealand Society of Animal Production, 76(2), 137-138.

Herwati, E dan M. Royani. 2017. Kualitas silase daun gamal dengan penambahan molases sebagai zat aditif. IJAS, 7(2), 29-32.

Kaunang, D. Suyadi, S. dan S. Wahjuningsih. 2012. Analisis litter size, bobot lahir dan bobot sapih hasil perkawinan kawin alami dan inseminasi buatan kambing Boer dan Peranakan Etawah. Jurnal Ilmu-Ilmu Peternakan, 23(3), 41-46.

National Research Council. 1981. Nutrient requirements of goats: angora, dairy, and meat goats in temperate and tropical countries. National Academy of Science: USA.

National Research Council. 2001. Nutrient requirements of dairy cattle. 7th rev. ed. National Academy of Science: USA.

Nnadi, P.A.; Kamalu, T.N. and Onah, D.N. 2007. Effect of dietary protein supplementation on performance of West African dwarf (WAD) does during pregnancy and lactation. Small Ruminant Res., 71(3), 200-204. doi: 10.1016/j.smallrumres.2006.06.007.

Novita, C.I., A. Sudono, I.K. Sutama, T. Toharmat. 2005. Produktivitas Kambing Peranakan Etawah yang diberi ransum berbasis jerami padi fermentasi. Media Peternakan, 29(2), 96-106.

Nuraini, Budisatria I.G.S, and A. Agus. 2014. Effect of the level of use of booster feed on the performance of the 
Bligon Goat Master on people's farms. Bulletin of Animal Husbandry, 38(1), 34-41.

Praveena Kulkarni, Kandenahalli C. Veeranna, Ramachandra B. Rao and Harisha Mageppa. 2014. Effect of supplementary feeding in Osamanabadi Goats: a participation action research analysis from India. Int. J. Agr. Ext., 2(3), 205-210.

Sahu, S., Babu, L.K., Karna, D.K., Behera, K., Kanungo, S., Kaswan, S., Biswas, P., and Patra, J.K. 2013. Effect of different level of concentrate supplementation on the periparturient growth performance of Ganjam Goat in extensive system. Vet. World, 6(7), 428-432.

Sirohi, A.S., A.K. Patel, B.K. Mathur, A.K. Misra, and M. Singh. 2014. Effects of steaming up on the performance of grazing does and their kids in arid region. Indian J. Anim. Res., 48(1), 7174. doi: 10.5958/j.0976-0555.48.1.015.
Soberon, F., E. Raffrenato, R.W. Everett, M.E. Van Amburgh. 2012. Preweaning milk replacer intake and effects on long-term productivity of dairy calves. Journal of Dairy Science, 95(2), 783793. doi: 10.3168/jds.2011-4391.

Sultana, S., Khan, M. J., Hassan, M. R. and Khondoker, M. A. M. Y. 2012. Effects of concentrate supplementation on growth, reproduction and milk yield of Black Bengal Goats (Capra hircus). The Bangladesh Veterinarian, 29(1), 7-16. doi: 10.3329/bvet.v9i1.11884.

Suranindyah, Y.Y., T.S.M. Widi, Sumadi, N.H. Tarmawati, and U. Dwisepta. (2009). Production Performance Of Etawah Cross Bred Goats In TuriSleman, Yogyakarta. Paper presented at The $1^{\text {st }}$ International Seminar on Animal Industry Bogor, (pp. 314-318). Bogor, Indonesia. 